\title{
Stage and season effects on cell cycle and apoptotic activities of germ cells and Sertoli cells during spermatogenesis in the spiny dogfish (Squalus acanthias)
}

\author{
L M McClusky \\ Department of Physiology, Faculty of Health Sciences, University of Pretoria, P.O. Box 2034, Pretoria 0001, \\ South Africa \\ Correspondence should be addressed to L M McClusky; Email: leon.mcclusky@med.up.ac.za
}

\begin{abstract}
To understand the processes involved in the spatial and temporal maturation of testicular cells in Squalus acanthias, we used standard morphometry, proliferating-cell nuclear antigen (PCNA) and terminal deoxynucleotidyl transferase-mediated dUTP nick end-labelling (TUNEL) immunohistochemistry. Except for immature spermatocysts (germinal zone, GZ; early-stage premeiotic, E-PrM), the number of cysts in all subsequent stages and the total number of cysts in the spermatogenic progression varied seasonally. The spermatogenic cycle spans about 2 years and is interrupted by germcell clone deletion via apoptosis at the mitosis-meiosis transition in April/May, manifesting as a zone of degeneration (ZD). Rate of displacement of the ZD across the testis diameter indicates that late-stage premeiotic (L-PrM) generations 12-13 require 9-10 months to reach the mature-spermatid stage. Also, the number of cysts completing spermatogenesis is approximately 4-5-fold less than the number that entered spermatogenesis proper 2 years earlier. Pronounced gonocytogenesis in the germinal ridge was coincident with ZD formation in April/May, but it was absent in the fall when mature spermatogonial and meiotic activities had resumed. Whereas strong Sertoli cell PCNA immunoreactivity dominated the GZ cyst cell-cycle activities throughout the year, except during the spring/summer months, the spermatogonial- and Sertoli-cell PCNA indices in E-PrM cysts were inversely related. PCNA immunoreactivity in spermatocytes was seasonal and dependent on the stage of meiosis. TUNEL labelling was limited to spermatogonia and increased stage-dependently in the $\operatorname{PrM}$ region (L-PrM $=$ mid-stage $\operatorname{PrM} \gg \mathrm{E}-\operatorname{PrM} \gg \mathrm{GZ}$ ), correlating with ZD formation, in a season-dependent manner. Results imply that effects of normal regulatory factors in Squalus are stage- and process-specific.

Reproduction (2005) 129 89-102
\end{abstract}

\section{Introduction}

Normal testicular development requires the spatiotemporal coordination of spermatogenic processes and development to ensure optimal production of spermatozoa. The founders of the germ-cell lineage, the spermatogonial stem cells, give rise to progeny that undergo a speciesspecific number of differentiating divisions (mitosis) and apoptosis before they enter meiosis (De Rooij \& Van Dissel-Emiliani 1997, De Rooij 2001). Studies primarily in adult rodents indicate that, of the numerous regulatory mechanisms present within the testis, density-dependent (De Rooij 2001, Tadokoro et al. 2002) and hormone-controlled (Meachem et al. 1999, Allan et al. 2004) mechanisms are two of the major physiological regulators that control these processes in an age-dependent and spermatogonial-stage-dependent manner. In addition, data obtained from organ cultures of immature rodent testes indicate that developing Sertoli cells influence the cellpopulation dynamics of gonocytes, and undifferentiated and differentiated spermatogonia, and their further maturation, depending on the age of the Sertoli cell (Boitani et al. 1993, 1995, Zhou et al. 1993, De Rooij \& Van Dissel-Emiliani 1997, Schlatt et al. 1999). Our knowledge of the inter-relationships between the different stages of spermatogonia and the various stages of Sertoli cell development in vivo is incomplete. Although it is known that germ cells are organized into clones and cohorts, it is not readily apparent whether Sertoli cells themselves are organized into clones, cohorts or groups to coordinate their inhibitory and stimulatory activities during their regulation of spermatogonial numbers in the germinal epithelium.

In contrast to that of the adult common laboratory rodent, spermatogenesis in the adult spiny dogfish shark, Squalus acanthias, is different in that spermatogonial proliferation (13 divisions in total) is accompanied by 
Sertoli-cell proliferation in a 1:1 ratio for the first nine divisions (Holstein 1969). S. acanthias is furthermore an ideal model in which to study spermatogenic processes stage by stage because its testicular organization is much simpler than that of the conventional laboratory rodent. In Squalus, the spermatogenic wave passes across the entire diameter of the testis (from the germinal ridge, containing the stem cells, to the mature pole), providing a readily visible zonation in testicular cross-sections of spermatocysts mainly in the premeiotic (PrM; spermatogonia and preleptotene spermatocytes), meiotic ( $M$; primary and secondary spermatocytes) or postmeiotic (PoM; round, elongating and mature spermatids) stages of development. Moreover, spermatogenesis in this and other shark species has a 'cystic' mode, in which a single germinal clone and a second clonal population of stage-synchronized Sertoli cells form an anatomically discrete follicle-like unit (spermatocyst). In addition, male germ cells in Squalus depend primarily on Sertoli cells for somatic cell support, since differentiated Leydig cells have not yet evolved at this phyletic level (Pudney \& Callard 1984).

Follow-up biochemical (Callard et al. 1995) and in situ fluorescence analyses (McClusky et al. 1996) to an initial report of Simpson \& Wardle (1967), which described a zone comprising several layers of degenerating germinal tissue that first appears naturally in May in S. acanthias at the spermatogonia-spermatocyte transition, confirmed the mode of death in this tissue as apoptosis. Since it has always been assumed that the month of May also marked the onset of the spermatogenically active period in Squalus (Callard et al. 1995, Piferrer \& Callard 1995), the observation of such a large stage-specific loss of testicular cells during presumed normal testicular recrudescence was indeed intriguing.

Proliferating cell nuclear antigen (PCNA) is used widely to provide an immunohistochemical assessment of cellcycle activity in normal tissues (Hall \& Woods 1990), and its expression is used as a marker of cell proliferation in cultured granulosa cells (the female equivalent of Sertoli cells) following their stimulation with follicle-stimulating hormone (FSH) and activin (El-Hefnawy \& Zeleznik 2001). PCNA, which is synthesized in early $G_{1}$ phase of the cell cycle, is an auxillary protein to $\delta$ and $\varepsilon$ DNA polymerases during the $S$ phase in cycling cells, and its immunoreactivity has a linear relationship with thymidine incorporation in a wide range of normal tissues (Hall \& Woods 1990). The terminal deoxynucleotidyl transferase (TdT)-mediated dUTP nickend-labelling (TUNEL) assay is now almost considered a classic apoptosis assay, in which the free $3^{\prime}-\mathrm{OH}$ ends of double-stranded DNA fragments that are formed preferentially in apoptotic cells are labelled (Gavrieli et al. 1992). Using standard morphometry, and immunohistochemistry of PCNA and TUNEL, the aims of this study were (1) to document the seasonal kinetics of spermatogenesis and (2) to elucidate the role of cell division versus cell death in germ cells and Sertoli cells at each developmental stage and time of year.

\section{Materials and Methods}

\section{Animals}

Mature male spiny dogfish, $S$. acanthias, were collected ( $n=3-8 /$ month) at various points during their annual run along the United States Atlantic coast through the facilities of the following institutions: January-March, North Carolina Division of Marine Fisheries (Cape Hatteras, NC, USA; $52-61 \mathrm{~cm}$ snout-vent length); AprilMay, Massachusetts Division of Marine Fisheries (Cape Cod Bay, MA, USA; 46-57 cm) and the Marine Biological Laboratory (MBL; Woods Hole, MA, USA; 43$55 \mathrm{~cm}$ ); June-September, Mount Desert Island Biological Laboratory (MDIBL; Salsbury Cove, ME, USA; 36$49 \mathrm{~cm})$; October-December, MBL $(39-58 \mathrm{~cm})$. Animals were killed by double-pithing via the olfactory canal or transection of the cervical spinal cord (Cape Hatteras samples only).

\section{Tissue preparation}

Cross-sections $(3-5 \mathrm{~mm})$ were taken midway along the length of one testis and fixed in $10 \%(\mathrm{v} / \mathrm{v})$ neutral buffered formalin (formaldehyde diluted 1:10 in elasmobranch balanced salt solution, EBSS) at $4^{\circ} \mathrm{C}$ for $24 \mathrm{~h}$. As reported previously (Callard et al. 1985), each cross-section includes a full spermatogenic sequence, and cross-sections are consistent throughout the length of the testis except at the anterior and posterior poles. Fixed tissues were washed twice in EBSS ( $1 \mathrm{~h}$ each), stored in cold $70 \%$ ethanol for no longer than 3-5 weeks, and embedded in Paraplast X-TRA (Oxford Labware, St Louis, MO, USA). Two consecutive $6 \mu \mathrm{m}$ sections (one each for PCNA and TUNEL) were floated on to a distilled water bath $\left(47^{\circ} \mathrm{C}\right)$, collected on slides pre-coated with poly-L-lysine $(1 \mathrm{mg} / \mathrm{ml}$, $M_{w} 33$ 000; Sigma) and allowed to air dry. Sections were then deparaffinized and rehydrated stepwise through an ethanol series.

\section{PCNA immunohistochemistry}

Immunostaining was carried out using the Unitect Avidin-Biotin-Peroxidase Immunohistochemistry Detection System Kit (Oncogene Science, Cambridge, MA, USA), which contains the recombinant PCNA mouse monoclonal PC10 antibody shown to interact with fish PCNA antigen (Ortego et al. 1994). The procedure was a modification of that suggested by the supplier. Endogenous peroxidase was quenched by treating sections in darkness for $10 \mathrm{~min}$ with $3 \%(\mathrm{v} / \mathrm{v})$ hydrogen peroxide. Following a rinse in distilled water, the sections were subjected to an antigen-retrieval procedure (Ortego et al. 1994), which involved heating in a microwave oven $(450 \mathrm{~W})$ in $1 \%(\mathrm{v} / \mathrm{v})$ anhydrous zinc sulphate for $3 \mathrm{~min}$, resting for $1 \mathrm{~min}$ and heating a further $3 \mathrm{~min}$. After cooling for $15 \mathrm{~min}$, sections were rinsed in distilled water 
and placed in $0.5 \%(\mathrm{v} / \mathrm{v})$ Tween 20 in PBS $(137 \mathrm{mM}$ $\mathrm{NaCl}, 29 \mathrm{mM} \mathrm{NaH} \mathrm{PO}_{4} \cdot \mathrm{H}_{2} \mathrm{O}$ and $9 \mathrm{mM} \mathrm{Na} \mathrm{HPO}_{4}, \mathrm{pH}$ 7.4; referred to here as $\mathrm{PBS}-\mathrm{A})$ for $5 \mathrm{~min}$. Sections were then incubated with $3.6 \%(\mathrm{v} / \mathrm{v})$ normal horse serum for $30 \mathrm{~min}$ at room temperature (RT) to reduce non-specific binding, and then overnight at $4^{\circ} \mathrm{C}$ with PCNA antibody diluted 1:200 (final concentration, $1 \mu \mathrm{g} / \mathrm{ml}$ ) in Tween 20/PBS-A. After three washes in PBS-A, sections were incubated with biotinylated horse secondary antibody for 30 min at RT, washed in PBS-A, and then incubated with the avidin-biotin complex for a further $30 \mathrm{~min}$ at RT. Following a 30-s rinse in 1\% (v/v) Triton X-100/PBS-A to reduce background staining, the antigen was finally detected by treating the sections, according to the supplier's instructions, for $3 \mathrm{~min}$ with a diaminobenzidine substrate kit (Vector Laboratories, Burlingame, CA, USA) that stained positive cells brown. Sections were counterstained with $0.5 \%$ (w/v) Methyl Green in $100 \mathrm{mM}$ sodium acetate $(\mathrm{pH} 4)$, dehydrated in $100 \%(\mathrm{v} / \mathrm{v})$ butanol, cleared in toluene and mounted with Permount (Fisher, Fair Lawn, NJ, USA). Negative controls were generated by substituting the primary antibody with the kit-supplied trp $\mathrm{E}$ antibody $(0.5 \mu \mathrm{g} / \mathrm{ml})$ and by serial dilution of the primary antibody. PCNA immunoreactivity was scored as (a) intense brown nuclear staining, (b) weak brown nuclear staining and (c) no staining. Each cyst was scored separately for PCNA-labelled germ cells or Sertoli cells, and PCNA staining of more than approximately $50 \%$ of nuclei of a given cell type was considered positive (not all cells in a clone are synchronized precisely).

\section{TUNEL immunohistochemistry}

Deparaffinized and rehydrated sections were treated with $0.1 \%(\mathrm{v} / \mathrm{v})$ Triton $\mathrm{X}-100$ in $0.1 \%(\mathrm{w} / \mathrm{v})$ sodium citrate for $3.5 \mathrm{~min}$ at RT, and washed twice with PBS-B $(50 \mathrm{mM}$ sodium phosphate, pH 7.4, and $200 \mathrm{mM} \mathrm{NaCl}$ ). Endogenous peroxidase was quenched by treating sections in darkness with $3 \%(\mathrm{v} / \mathrm{v})$ hydrogen peroxide for $7 \mathrm{~min}$, followed by two washes in PBS-B. Subsequent steps for TUNEL staining were carried out using the ApopTag-Peroxidase Kit according to the supplier's instructions (Oncor, Gaithersburg, MD, USA), except that the terminal transferase enzyme (TdT) was diluted 1:16 with sterile water. Following incubation of the sections with the TUNEL reaction mixture in a humidified chamber at $37^{\circ} \mathrm{C}$ for $1 \mathrm{~h}$, anti-digoxigenin-peroxidase complex was added for 30 min at RT. Sections were then treated with diaminobenzidine, counterstained and mounted as described for PCNA. To generate negative controls, TdT was replaced with sterile water, whereas for positive controls sections were pretreated with DNase I (Sigma; $10 \mu \mathrm{g} / \mathrm{ml}$ in distilled water) to generate DNA fragments. For TUNEL scoring, spermatocysts containing more than three TUNEL-positive cells were considered apoptotic, a standard previously applied to rat tubules (Lee et al. 1997).

\section{Microscopy}

Quantitative measurements were carried out using an Olympus $\mathrm{BH} 2$ microscope with a graticule-containing eyepiece and an attached Hamamatsu C2400 CCD camera serially connected to a Sony monochrome video monitor and a Power Macintosh computer equipped with an AG-5 frame-grabber card (Scion Corporation, Frederick, MD, USA) and NIH Image software (version 1.62). All cysts along three lines radiating from the point of origin of cyst development (the germinal ridge) to the proximal border of the peripherally located epigonal organ at the mature testicular pole were counted, classified by stage and scored for PCNA or TUNEL immunoreactivity (total per animal, 240-300 cysts). Since the developmental progression is accompanied by changes in cyst diameter (see Table 1 below), cyst counts were adjusted for the width of a testicular cross-section at the midpoint of the segment occupied by each stage as follows:

$$
N_{\text {cyst }}, \quad x a=t w / d_{\text {cyst }} \cdot I_{\text {count }}
$$

where $N_{\text {cyst, }}$ xa is the number of cysts/cross-sectional area per stage, tw is testis width at the midpoint of each cyst stage $(\mu \mathrm{m}), d_{c y s t}$ is the mean diameter of each cyst stage $(\mu \mathrm{m})$ and $\mathrm{I}_{\text {count }}$ is the mean number of cysts counted on three radiating lines at each stage.

\section{Statistics}

For each time point, data were expressed as the mean total number of cysts in the spermatogenic progression and in each substage (per cross-section; see Fig. 1 below), the fractional distribution of different substages as a percentage of the total number of cysts (see Fig. 2 below) and the mean percentage of cysts with PCNA-labelled germ cells, PCNA-labelled Sertoli cells and TUNEL-labelled germ cells at each substage (see Figs 5 and 7 below). The raw percentage data were arcsine square-root-transformed prior to testing for differences. Data were examined by one- and two-way ANOVA (see figure legends) using SigmaStat, version 2.0 (Jandel Scientific, San Rafael, CA, USA). The Student-Newman-Keuls multiple-comparisons test was used to determine which values differed significantly $(P<0.05)$.

\section{Results}

\section{Staging criteria}

To standardize morphometric analyses, the staging criteria and the nomenclature used for different substages were adopted after initial light-microscopic and immunohistochemical observations of the full seasonal series. As summarized in Table 1, staging criteria were based on (a) position of the cyst in the testis cross-section relative to the germinal ridge (maturational order), (b) cyst diameter and (c) cyst organization with respect to relative numbers and positions of germ-cell versus Sertoli-cell nuclei, as 
Table 1 Criteria used for classification of spermatocysts during the spermatogenic progression and stage-related patterns of PCNA and TUNEL immunohistochemistry during annual cycle in S. acanthias.

\begin{tabular}{|c|c|c|c|c|c|c|c|c|c|}
\hline Substage (zone) & $\begin{array}{l}\text { Germinal } \\
\text { ridge }(G R)\end{array}$ & $\begin{array}{l}\text { Germinal } \\
\text { zone }(G Z)\end{array}$ & $\begin{array}{c}\text { Early (e-) } \\
\text { premeiotic }\end{array}$ & $\begin{array}{c}\text { Mid (m-) } \\
\text { premeiotic }\end{array}$ & $\begin{array}{c}\text { Late (l-) } \\
\text { premeiotic }\end{array}$ & Meiotic & $\begin{array}{c}\text { Early (e-) } \\
\text { postmeiotic }\end{array}$ & $\begin{array}{c}\text { Mid (m-) } \\
\text { postmeiotic }\end{array}$ & $\begin{array}{c}\text { Late (I-) } \\
\text { postmeiotic }\end{array}$ \\
\hline Cyst diameter $(\mu \mathrm{m})$ & $10-15$ & $15-60$ & $60-150$ & $150-300$ & $300-380$ & $380-400$ & $400-420$ & $340-360$ & $250-290$ \\
\hline Stage of germ cell development & $\begin{array}{c}\text { Gonocytes \& } \\
1^{\circ} \text { s'gonia }^{\prime}\end{array}$ & $1^{\circ} \mathrm{s}^{\prime}$ gonia & $2^{\circ} \mathrm{s}^{\prime}$ gonia & $2^{\circ} \mathrm{s}^{\prime}$ gonia & $2^{\circ} \mathrm{s}^{\prime}$ gonia & $1^{\circ} \& 2^{\circ} \mathrm{s}^{\prime}$ cytes & Round s'tids & Elongating s'tids & Mature s'tids \\
\hline${ }^{\mathrm{a} S}$ Spermatogonial generation & $1-2$ & $2-4$ & $5-9$ & $10-11$ & $12-13$ & $\mathrm{NA}$ & NA & NA & NA \\
\hline Lumen & No & Yes & Yes & Yes & Yes & Yes & Yes & Yes & Yes \\
\hline Location: Sertoli-cell nuclei & Random & Random & Adluminal & Adluminal & $\begin{array}{c}\text { Migrating } \\
\text { peripherally }\end{array}$ & Peripheral & Peripheral & Peripheral & Peripheral \\
\hline Number of germ cell layers & NA & NA & $1-3$ & $4-8$ & $8-9$ & $8-9$ & $9-11$ & NA & NA \\
\hline${ }^{\mathrm{a}}$ Germ-cell:Sertoli-cell ratio per cyst & $1: 1$ & $1: 1$ & $1: 1$ & $2-8: 1$ & $8-16: 1$ & $16-64: 1$ & $64: 1$ & $64: 1$ & $64: 1$ \\
\hline${ }^{\mathrm{a}}$ Number of Sertoli cells per cyst & $1-8$ & $8-16$ & $32-512$ & 512 & 512 & 512 & 512 & 512 & 512 \\
\hline $\mathrm{d}_{\%}$ Cysts with PCNA-positive germ cells & $\begin{array}{l}\text { Low - high, } \\
\text { seasonal }\end{array}$ & $\begin{array}{l}\text { Low - high, } \\
\text { seasonal }\end{array}$ & $\begin{array}{l}{ }^{\mathrm{C}} \text { Low - high, } \\
\text { seasonal }\end{array}$ & $\begin{array}{l}\text { High, year } \\
\text { round }\end{array}$ & $\begin{array}{l}\text { High, year } \\
\text { round }\end{array}$ & $\begin{array}{l}\text { bLow - high, } \\
\text { seasonal \& } \\
\text { stage-related }\end{array}$ & None & None & None \\
\hline $\mathrm{d}_{\%}$ C Cysts with PCNA-positive Sertoli cells & $\begin{array}{c}\text { Low - high, } \\
\text { seasonal }\end{array}$ & $\begin{array}{c}\text { Low - high, } \\
\text { seasonal }\end{array}$ & $\begin{array}{c}{ }^{\mathrm{c}} \text { Low - high, } \\
\text { seasonal }\end{array}$ & None & None & None & None & None & None \\
\hline $\mathrm{d}_{\%}$ Cysts with TUNEL-positive germ cells & None & None & Low & $\begin{array}{c}\text { Low - high, } \\
\text { seasonal }\end{array}$ & $\begin{array}{c}\text { Low - high, } \\
\text { seasonal }\end{array}$ & None & None & None & None \\
\hline $\mathrm{d}_{\%}$ Cysts with TUNEL-positive Sertoli cells & None & None & None & None & None & None & None & None & None \\
\hline
\end{tabular}

${ }^{a}$ Estimates based on Holstein (1969).

${ }^{\mathrm{b}}$ Cell cycle stage-dependent: intense (leptotene $\rightarrow$ early pachytene); weak or negative (mid $\rightarrow$ late pachytene)

${ }^{c}$ Labelling of germ cell and Sertoli cells alternates.

report.

NA, not applicable; s'gonia, spermatogonia; s'cyte, spermatocyte; s'tid, spermatotid. 
described in earlier studies of this and other dogfish species (Stanley 1966, Simpson \& Wardle 1967, Holstein 1969). For example, based on actual cell counts per spermatocyst, Sertoli cells have been reported to undergo nine, and germ cells an additional four, mitotic divisions in Squalus (Holstein 1969). However, the cyst size associated with the cessation of Sertoli-cell proliferation, an important landmark in the PrM region, cannot be discerned by routine histological methods. Thus, in this analysis, the transition from PCNA-positive to -negative

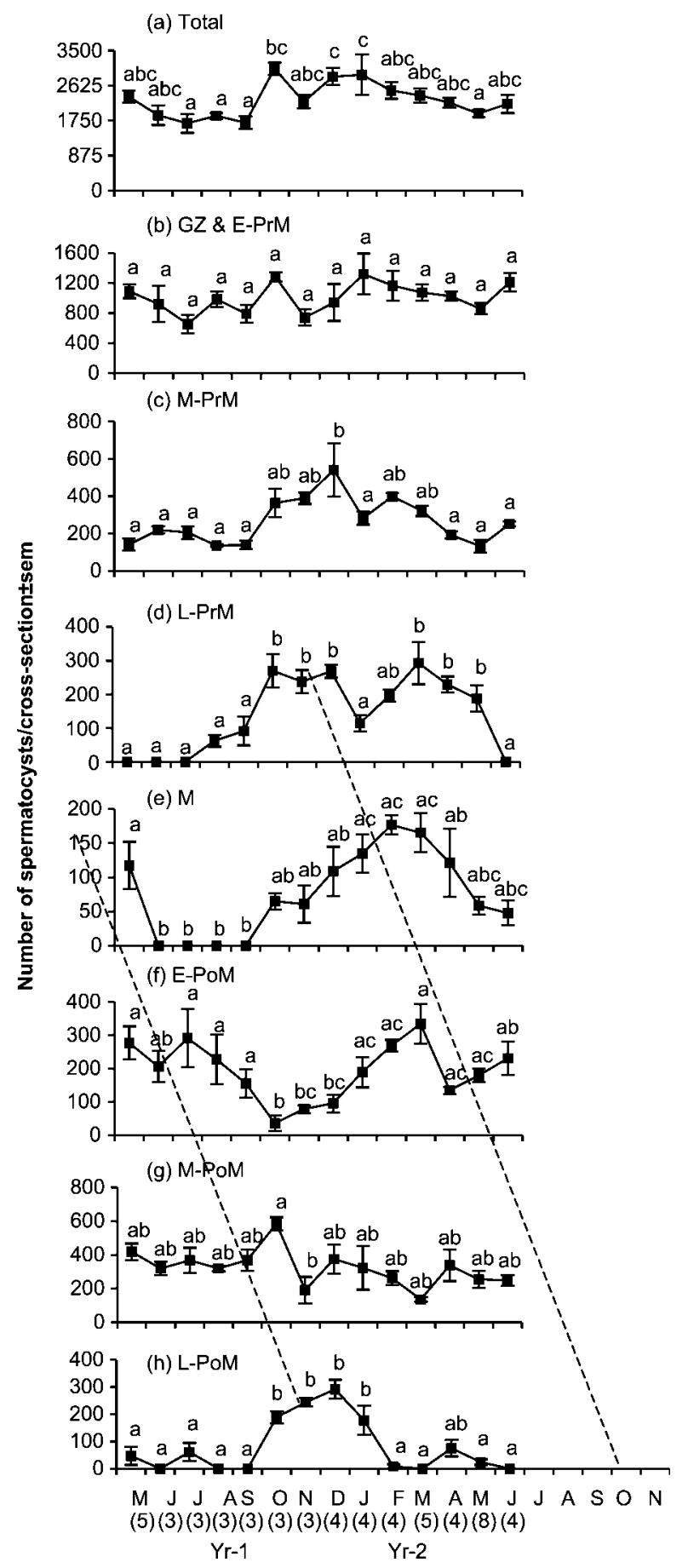

Sertoli-cell nuclei was used to demarcate early- and midstage PrM cysts. In addition to the substages defined in Table 1 and quantified in Fig. 1, several layers of degenerating cysts comprising a zone of degeneration (ZD) were located at different positions relative to the germinal ridge and other stages (Fig. 2 and see Fig. 6f, below). Also, large, empty cysts with a few loose spermatids and prominent peripheral Sertoli-cell nuclei were located beneath the capsule at the mature surface of the testis at some times of the year and designated evacuated cysts (Fig. 2, and see Fig. $4 b$, below).

\section{Seasonal variations in the number, fraction and spatial distribution of staged spermatocysts}

To examine seasonal effects on spermatogenic progression, the number (Fig. 1) and fraction (Fig. 2) of developing cysts at defined substages were quantified monthly over a full annual cycle. In order to account for changes in cyst diameter during developmental progression, the formula used for the calculation of cyst counts incorporated the parameters of testis width and mean cyst diameter of each stage. Except for immature spermatogonial cysts (germinal zone (GZ) and early-stage PrM (E-PrM) cysts; cyst diameter, 15-150 $\mu \mathrm{m}$; Fig. $1 \mathrm{~b}$ ), the number of cysts in all subsequent stages (Fig. $1 c-1 h$ ) and the total number of cysts (Fig. 1a) varied with time of year $(P<0.001)$. Regardless of time of year, approximately $50-70 \%$ of germinal clones were in PrM stages of development, $25-40 \%$ in PoM stages and $<10 \%$ in meiosis (Fig. 2). Although spermatogonial cysts (GZ, E-PrM and mid-stage PrM (M-PrM) cysts) were the most abundant cyst stages (approximately 1200 cysts compared with a total of approximately 750 cysts for the rest of the stages) in the spermatogenic progression (Fig. 1) in May/JuneAugust, testis width was nevertheless at its yearly minimum, because it completely lacked late-stage PrM (L-PrM) cysts (Figs. $1 d$ and 2) and M-stage cysts (spermatocytes; Figs. $1 e$ and $2 ; P<0.05)$, the two cyst stages which together have the largest cyst diameters. Conversely, during the fall/early winter months, testis width reached

Figure 1 Seasonal changes in the number of spermatocysts at defined spermatogenic substages in $S$. acanthias. Values represent the mean number of spermatocysts \pm S.E.M. per testicular cross-section (see the Materials and methods section). Note scale differences on the $y$-axis of each panel. Untransformed values were analyzed by one-way ANOVA. Seasonal variations were significant in all stages $(P<0.001)$ except (b). Within each stage, data points with different letters differed significantly $(P<0.05)$ from each other. Numbers of animals collected monthly for this and all subsequent analyses are shown in parentheses at the bottom of the figure. Letters at the bottom indicate months of the year starting at the left with May (M). Criteria used in substaging are described in Table 1. GZ, germinal zone; E-, M-, L-PrM, early-, mid-, late-stage premeiotic cysts; E-, M-, L-PoM, early-, mid- and late-stage postmeiotic cysts. Dashed lines indicate the temporal progression of spermatogenesis by extrapolating back from peak production of L-PoM cysts to the previous season's peak of M-stage cysts, and forward from the current M-stage cysts to next season's cysts with mature spermatids (L-PoM). 


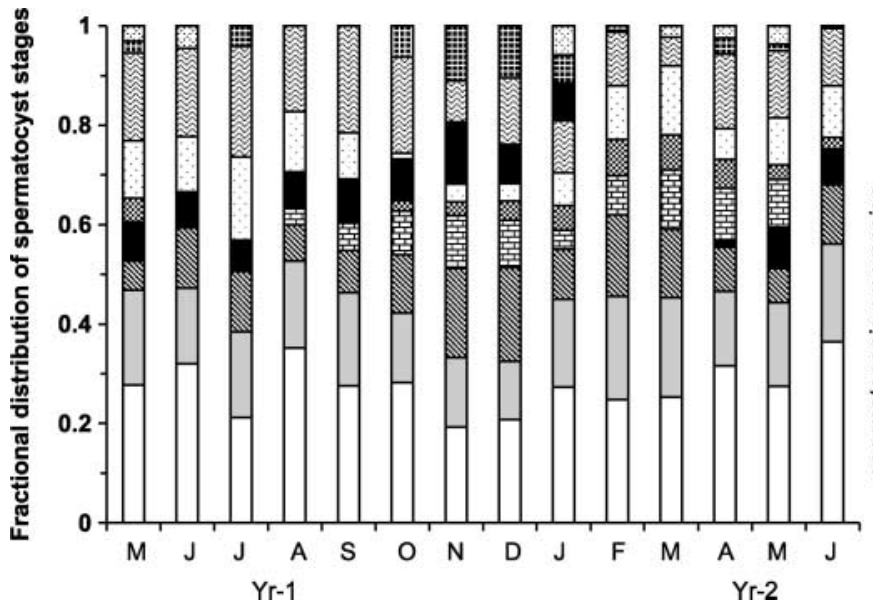

its maximum, due to the resumption of mature spermatogonial development (L-PrM; Figs $1 d$ and 2), leading to transition into meiosis ( $M$ stage; Figs $1 e$ and 2 ), and subsequently the formation of round and elongating spermatids (Figs $1 f, 1 g$ and $2 ; P<0.05$ ). If the temporal progression of spermatogenesis is traced by extrapolating back from the peak accumulation of L-PoM cysts (mature spermatids), or by extrapolating forward from the peak accumulation of M-stage cysts (spermatocytes; Fig. 1, dotted lines), it is evident that germinal clones in the final stages of spermiogenesis entered meiosis approximately 9-11 months earlier. Although the peak number of cysts was 4-5-fold greater at the beginning than at the end of spermatogenesis (approximately 1200 versus 300; compare Fig. $1 b$ and $1 h$ ), this estimated net loss of developing clones, though conservative, may be even greater as the actual net loss cannot be computed from these data without knowing the duration of intervening substages.

The spatial and temporal appearance of the ZD in April (year 2), interposed between M-PrM and L-PrM stages, preceded a deficit of L-PrM cysts initially and M-stage cysts later between May and September (Fig. 2; $P<0.004)$. The temporal troughs in all cyst stages subsequent to the M-PrM stage (Fig. $1 d-1 g ; P<0.05$ ) correspond exactly with the position of the ZD in time and space in the spermatogenic progression (Fig. 2; $P<0.004)$. Once formed, the number of cysts in $\mathrm{ZD}$ did not change (187 \pm 12.88 (mean \pm S.E.M.) ), suggesting that degenerate cysts were neither added nor entirely reabsorbed as the season progressed. The spatiotemporal displacement of the ZD occurs as a result of the resumption of premeiotic activities and the mitosis-meiosis transition behind the ZD band in August (Fig. 2; $P<0.004$ ). The rate of advance of $Z D$ observed in this and an earlier study (Simpson \& Wardle 1967) indicates that spermatogonial generations 12-13 (L-PrM cysts) require 9-10 months to reach the mature-spermatid stage. The first appearance of evacuated cysts in January agrees with the reported time of spermiation and mating in the Atlantic stocks of this species (Simpson \& Wardle 1967). Consistent with the data in Fig. 1, these results suggest that the

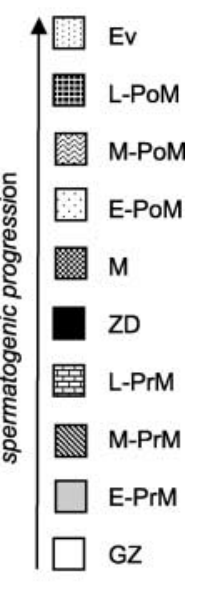

Figure 2 Seasonal changes in the fractional compo-
sition and spatial arrangement of staged spermato-
cysts in the developmental progression (vertical
arrow) in $S$. acanthias. Values represent the mean
percentages of cysts at a given stage relative to the
total number per cross-section at each time point
(see Fig. 1 for actual values \pm S.E.M.). Percentage
values were arcsine square-root-transformed and
analyzed by one-way ANOVA. Except for GZ and
E-PrM cysts, all stages varied significantly by time
of year $(P<0.004)$. Numbers of animals collected
and abbreviations are shown in Fig. 1 . Ev, evacu-
ated cysts.

developmental progression from newly formed spermatocysts in the germinal ridge to cysts with fully mature spermatids requires two annual cycles, interrupted by a summer period of developmental arrest at the spermatogonium-spermatocyte and the elongating-spermatidmature-spermatid transitions. This interpretation is consistent with a 2-year cycle of folliculogenesis, ovulation, mating, gestation and parturition in females of the same species (Simpson \& Wardle 1967, Jones \& Geen 1977).

\section{PCNA immunoreactivity}

To determine how seasonal variations in the formation of new cysts, and the expansion of germinal- and Sertoli-cell clones in developing cysts, contribute to the spermatogenic progression, PCNA immunohistochemistry was used to observe and quantify cell-cycle activity of germ cells and Sertoli cells in the testis (Figs. 3-5). As shown in Fig. $3 a-3 c$, the longitudinal germinal ridge was tonguelike in shape and collapsed when prespermatocyst stem cells (gonocytes and Sertoli-cell precursors) lacked PCNA immunoreactivity (September-March), but had a rigid triangular shape when clusters of PCNA-positive germ cells were present (April-August). Although the number of cells in the germinal ridge was not counted, this spring/ summer period of stem-cell proliferation (Fig. 5, horizontal bars) was coincident with the seasonal appearance of the ZD (Fig. 2). Once formed, each subsequent spermatocyst stage had a unique PCNA-labelling pattern with regards to both germ and Sertoli cells (Fig. 4). In contrast to mature spermatogonial cysts (M-PrM and L-PrM cysts), PCNA labelling in immature spermatogonial cysts was characterized by season-dependent alternating peaks in germ-cell and Sertoli-cell labelling, which was already evident in GZ cysts and was more pronounced in E-PrM cysts (GZ, Fig. 5a, germ-cell index, $P<0.001$; Sertoli-cell index, $P<0.03$; E-PrM cysts, Fig. 5b, germ-cell index, $P<0.05$; Sertoli-cell index, $P<0.002$ ). Thus, in these two stages, when germ cells were labelled, Sertoli cells were not, and vice versa, and all cells of each type in a given cyst were synchronized in or out of the cell cycle 

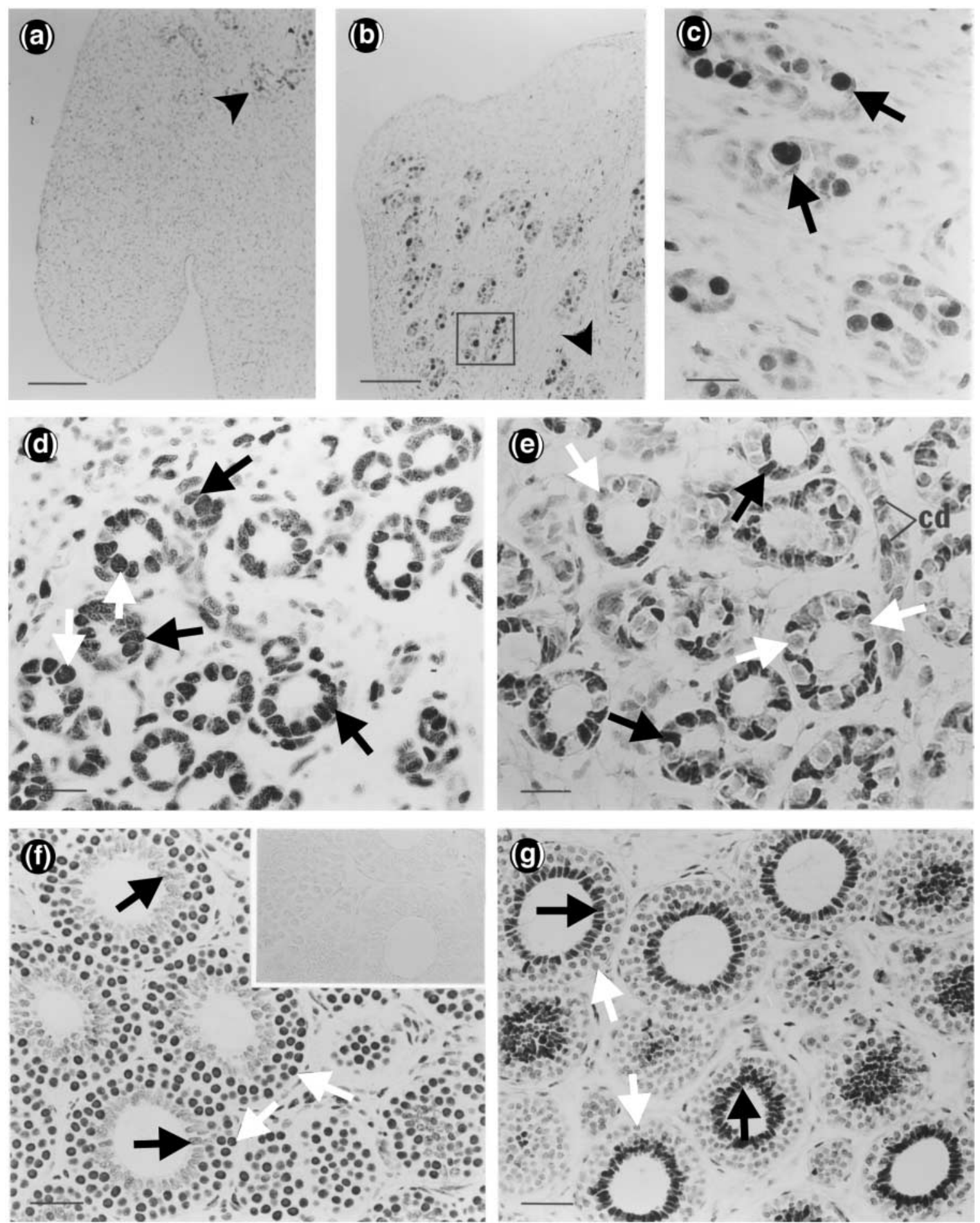

Figure 3 Photomicrographs showing PCNA immunolabelling of PrM spermatocysts at different substages and times of year (Methyl Green counterstained) in S. acanthias. Germinal ridge showing stem cell nests when gonocytogenesis is (a) inactive in December and (b) active in June. For orientation, the position of the GZ (the next stage in maturation) is shown (arrowhead). (c) High magnification of boxed area in (b) showing PCNA labelling of gonocytes but not somatic (pre-Sertoli) elements (arrows). (d and e) GZ region showing earliest stages of spermatocyst formation. In (d), both spermatogonial (white arrows) and Sertoli-cell nuclei (black arrows) are PCNA-positive (August). In (e) spermatogonia (white arrows) are PCNA-negative, but Sertoli nuclei (black arrows) are PCNA labelled (November). Note labelling of nuclei of collecting ductules (cd), which become patent at the end of spermatogenesis. ( $f$ and g) E-PrM-stage spermatocysts showing alternating pattern of PCNA labelling: (f) labelled spermatogonia (white arrows) and unlabelled adluminal Sertoli nuclei (black arrows; August), and (g) labelled Sertoli nuclei (black arrows) and unlabelled peripheral spermatogonia (white arrows; November). Inset in ( $\mathrm{f}$ ) shows negative control (no primary antibody). Scale bars: (a, b), $100 \mu \mathrm{m}$; (c), $20 \mu \mathrm{m}$; (d-g), $25 \mu \mathrm{m}$. 

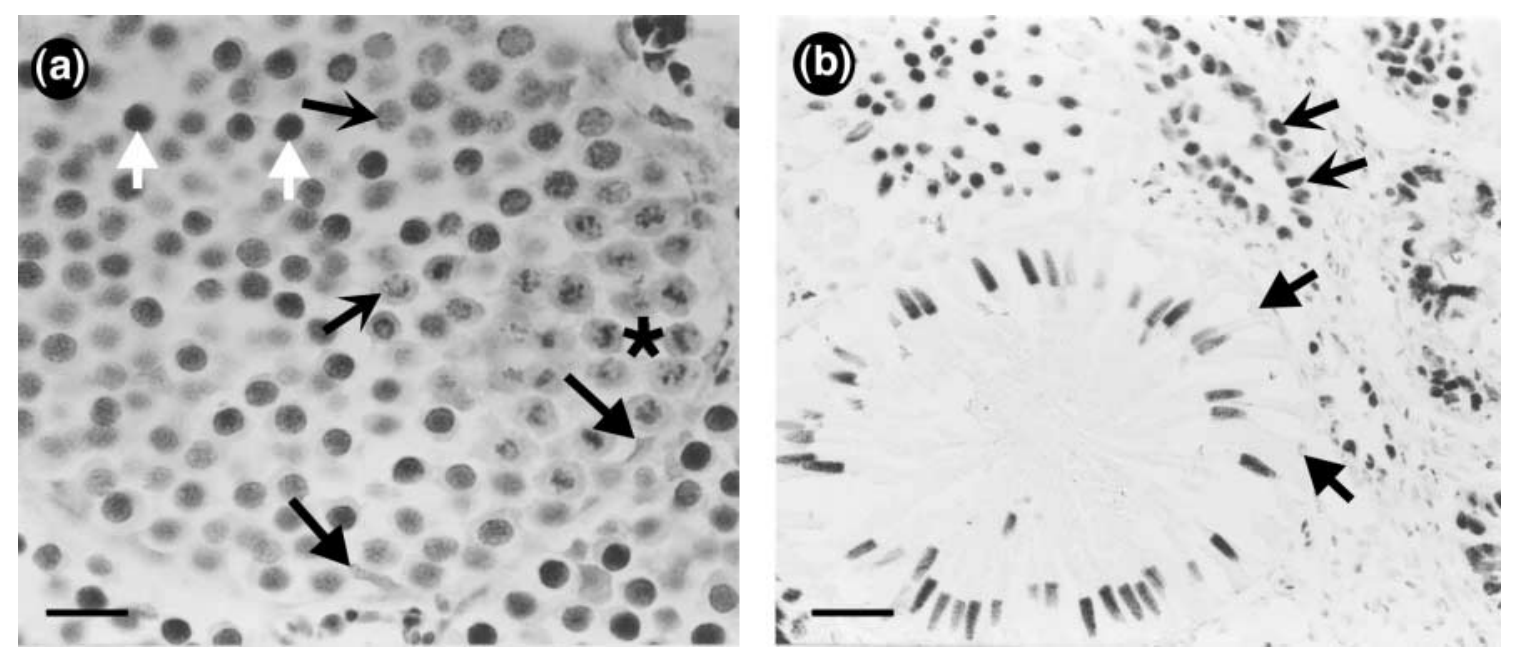

Figure 4 Photomicrographs showing PCNA immunolabelling of M- and PoM-stage spermatocysts (Methyl Green counterstained) in S. acanthias. (a) In a single spermatocyst, intensity of PCNA labelling of spermatocytes decreases from intense (white arrows) to weak (concave-headed arrows) as meiotic division proceeds. Area containing nuclei with Methyl Green-stained metaphase chromosomes is indicated by*. Note the absence of labelling of Sertoli cells in spermatocyte cysts (straight-headed arrows). (b) Spermatocysts with mature spermatid bundles are PCNAnegative, as are Sertoli nuclei (straight-headed arrows), but bundled spermatid heads are strongly Methyl Green-stained. Note strongly PCNApositive Sertoli nuclei in evacuated cyst (concave-headed arrows). Scale bars: $20 \mu \mathrm{m}$ (a) and $25 \mu \mathrm{m}$ (b).

(Fig. $3 d-3 g$ ). The alternating cell-type-dependent PCNA labelling in the immature spermatogonial cysts was also stage-dependent; i.e. the Sertoli-cell PCNA index was $\mathrm{GZ} \gg \mathrm{E}-\operatorname{PrM}(P<0.001)$ and the germ-cell PCNA index was $\mathrm{GZ} \ll \mathrm{E}-\operatorname{PrM}(P<0.001)$. Sertoli cells of M-PrM and $\mathrm{L}$ - PrM cysts (when these cysts were present) were consistently PCNA-negative, while M-PrM-cyst spermatogonia averaged a PCNA-labelling index of $50 \%$ or more during the year (Fig. 5 C). In addition, the germ-cell PCNA indices of L-PrM and M-stage cysts (when they were present) varied seasonally (Fig. $5 d$, L-PrM, $P<0.001$; Fig. 5e, M stage, $P<0.03)$, with both cyst stages lacking PCNA immunoreactivity in summer. PCNA immunostaining in M-stage cysts was also dependent on the stage of meiosis (Fig. 4a). Secondary spermatocyte, round, elongating (all not shown) and mature-spermatid cysts (Fig. 4b) were consistently PCNA-negative for all cell types. By contrast, Sertoli cells in evacuated cysts were strongly PCNAimmunoreactive (Fig. 4b), which is unlikely to be an artifact because Sertoli cells in adjacent mature-spermatidcontaining cysts in the same section and negative controls (not shown) were not PCNA-labelled.

\section{TUNEL labelling}

To examine the cellular basis of ZD formation, and the role of apoptosis in the seasonal onset, offset and progression of spermatogenesis, TUNEL immunohistochemistry was used to identify apoptotic cells. TUNEL labelling had distinct spatial (stage-dependent; Fig. 6) and temporal (seasonal; Fig. 7) patterns. TUNEL-positive staining was limited to spermatogonia, never observed in GZ cysts (not shown), occasionally seen in E-PrM cysts (Fig. $6 a$ and $6 b$ ) and observed frequently in M-PrM (Fig. 6C), L-PrM (Fig. 6e) and ZD cysts (Fig. 6f) in a season-dependent manner.
TUNEL labelling inside individual cysts took on several forms, indicative of the progression from early to late stages of the degenerative process: (a) scattered, single, small TUNEL spots, consistent with the labelling of fragmented DNA in individual spermatogonial nuclei, in otherwise normal cysts (Fig. 6b); and (b) very large TUNEL spots, consistent with labelling of fragmented DNA in multinucleate germ cells (Fig. $6 c$ and $6 e$ ).

As stated above, a cyst was considered TUNEL-positive if it had three or more TUNEL-positive germ cells. Temporally, the total TUNEL index for the entire PrM region was at its lowest $(2-8 \%)$ during the mid-winter period (December-February), after which, starting in April and through to September, it reached maximum levels in a distinct stage-dependent manner $(P<0.001)$. The most frequently labelled germinal clones were M-PrM cysts (TUNEL index increased to $20-55 \%$ between April and September, $P<0.001$ ), indicating that further development of these cysts in early summer would cease as they would form the current season's ZD (Fig. 7). Although L-PrM cysts (spermatogonial generations 12/13) were absent from the spermatogenic progression between May and July (year 1), the result of M-PrM cysts aborting and forming the ZD, their TUNEL index was high (20-45\%) when a few cysts in this stage were seen at the trailing edge of ZD in August and September (Fig. 7; $P<0.001$ ). The TUNEL index of E-PrM cysts never exceeded $10 \%$ of the total cyst population (Figs. 6a, $6 b$ and 7; $P<0.001$ ), regardless of the time of year. A complete apoptotic E-PrM cyst, with Sertoli cells of normal appearance and positioning, was observed only once during the summer in the full seasonal series (Fig. 2B in Callard et al. 1998), but their rare observation could perhaps be explained by either their rapid removal and/or their low susceptibility to apoptosis. However, all 
cell types and stages were labelled after DNase I treatment of tissue sections, evidence that the observed negative labelling was actually due to the absence of fragmented DNA rather than a lack of access of TUNEL reagents in situ (Fig. 6h). Specific staining was further verified in the

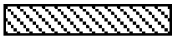

(a) GZ

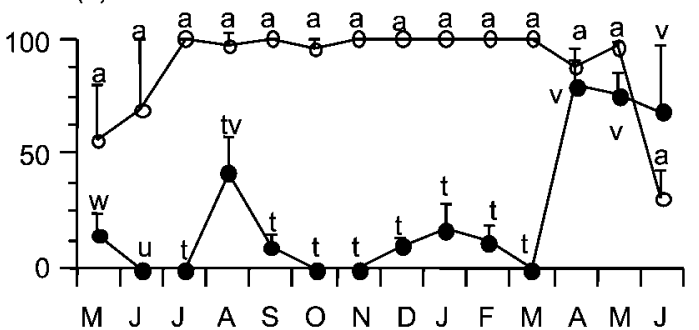

(b) E-PrM

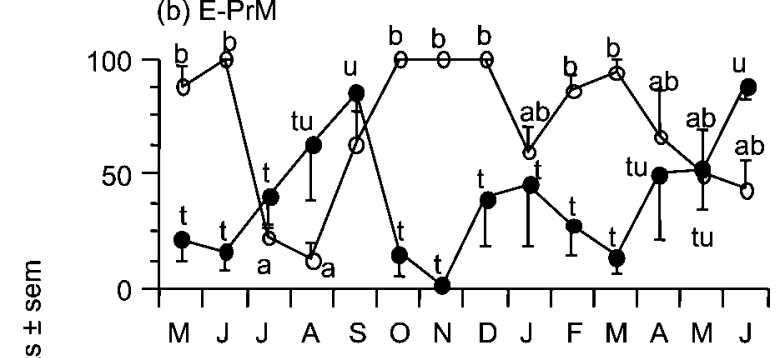

(c) M-PrM

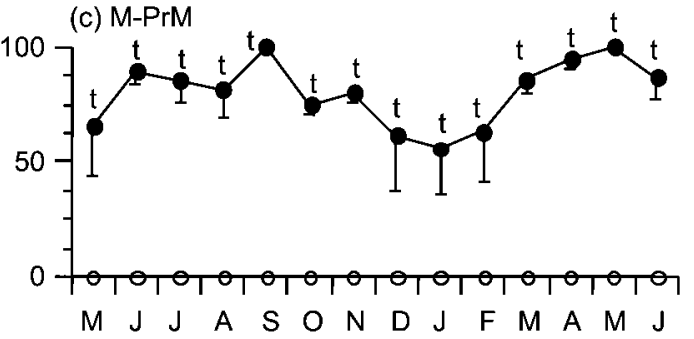

(d) L-PrM

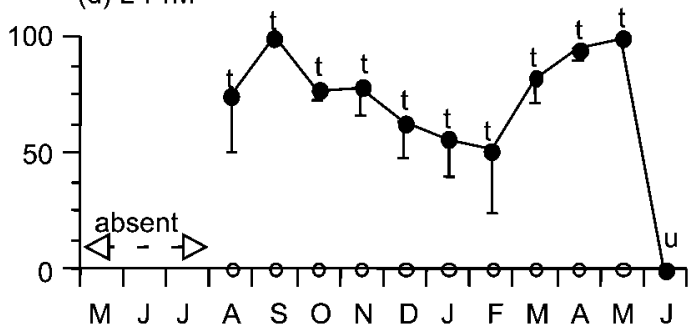

(e) M

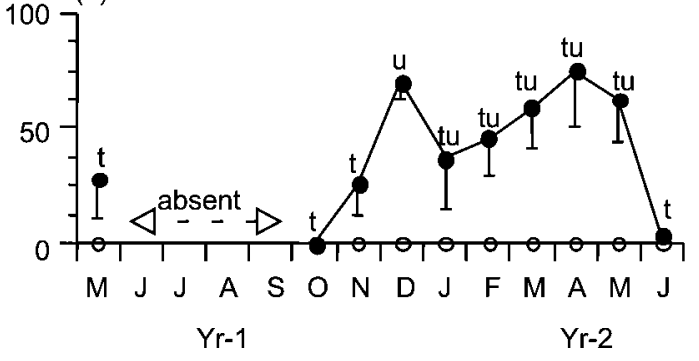

negative-control reaction, which lacked any background labelling (Fig. $6 d$ ). Moreover, a regular observation in this study and those of others (Simpson \& Wardle 1967), was that of ZD-like-shaped cysts (oval-shaped) at the trailing edge of the ZD in sharks caught in August-October, and which apparently recovered and a few months later developed to contain some maturing spermatids.

\section{Discussion}

This study is the first to quantitatively correlate seasonal variations in the number and proportions of various spermatocyst stages with cell-proliferative and cell-death activities at each stage during the spermatogenic cycle in a squalomorph elasmobranch (S. acanthias). Although all spermatocyst stages appear to be present all year round, the protracted spermatogenic cycle of 2 years causes temporal overlapping in the developmental peaks of early and late spermatocyst stages in consecutive years. Thus, even though the peak in the numbers of mature spermatogonial cysts coincides in time and space with the peak in the numbers of mature spermatid cysts in one annual cycle, the latter really represents the completed development of germ-cell clones that entered the M-PrM-cyst stage approximately 1 year earlier. A major factor contributing to the protracted spermatogenic cycle in Squalus is that spermatogenic development is characterized by substantial clonal deletion. Specifically, the number of germinal clones completing spermatogenesis (i.e. mature spermatid cysts) is approximately $4-5$-fold less than the number of germinal clones that entered the differentiative pathway (i.e. GZ and E-PrM cysts) 2 years earlier. Analysis reveals that the most earliest spermatogenic stage in the progression, showing a 4-5-fold seasonal reduction in its numbers, is the M-PrM stage (the first spermatogonial cyst stage with postmitotic Sertoli cells). Consequently, the temporal peaks and troughs in M-PrM cyst numbers are also reflected in subsequent spermatogenic stages over the ensuing months. Results show that the 4-5-fold loss of M-PrM cysts (the aborted cysts become the ZD) from the spermatogenic progression at the spring-summer

\footnotetext{
Figure 5 Seasonal and stage-related changes in the percentage of spermatocysts with PCNA immunolabelling of germ cells $(\bullet)$ and Sertoli cells $(O)$ in $S$. acanthias. Percentage values were arcsine square-root-transformed and analyzed by two-way ANOVA ( $a$ and b) and one-way ANOVA (c-e), followed by the Student-NewmanKeuls multiple-comparison test. The significance of the monthly variations at each stage was: GZ (germ cells, $t-w, P<0.001$; Sertoli cells, $\mathrm{a}-\mathrm{b}, P<0.03$ ); $\mathrm{E}-\operatorname{PrM}$ (germ cells, $\mathrm{t}-\mathrm{w}, P<0.05$; Sertoli cells,

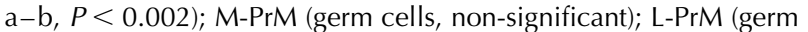
cells, $P<0.001$ ); M (germ cells, $P<0.03$ ). For GZ (a) and E-PrM (b), the interaction between cell type and time of year was significant $(P<0.001)$. In $(\mathrm{d})$ and $(\mathrm{e})$, cysts in these categories were absent at certain times of year (see Figs. 1 and 2). Sertoli cells were PCNAnegative after E-PrM stages, and germ cells after M-stages (see Fig. 3). For reference, horizontal bars above (a) show period of stem-cell proliferation in the germinal ridge (cells not quantified).
} 

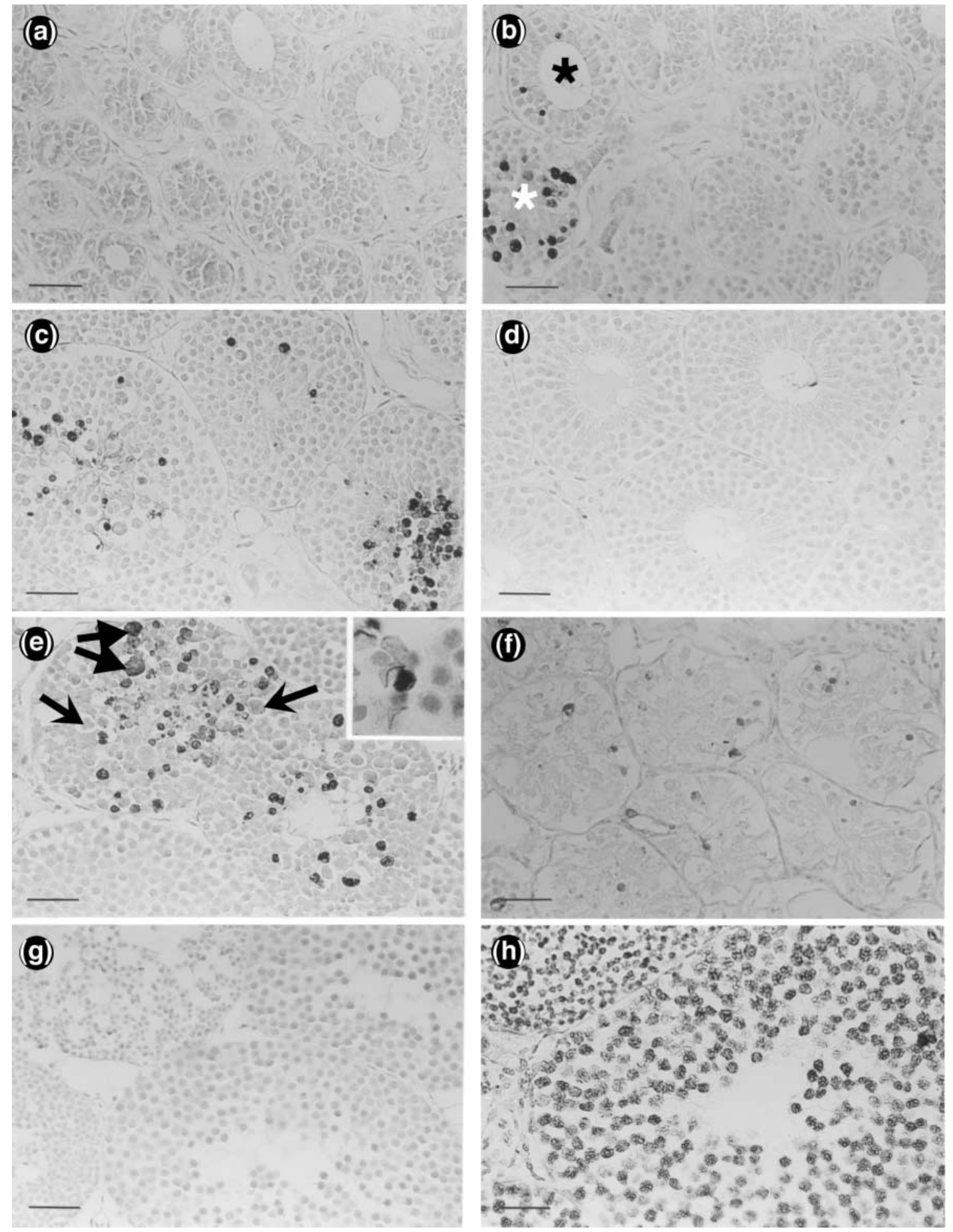

Figure 6 Photomicrographs of spermatocysts after TUNEL staining (May/June). GZ (not shown) and (a) E-PrM cysts are usually unlabelled, but (b) a few E-PrM cysts have a small number of TUNEL-positive germ cells (black star) or very occasionally are degenerate (white star). (c) TUNELpositive germ cells are frequently observed in M-PrM cysts of $S$. acanthias. (d) Negative control of PrM cyst (no TdT). (e) L-PrM spermatocyst earmarked for degeneration with numerous TUNEL-labelled nuclei. Multinucleated giant cells may be TUNEL-negative (concave-headed arrows) or, more often, TUNEL-positive (straight-headed arrows). Inset: Sertoli-cell nucleus of a ZD cyst closely apposed to a phagocytosed germ-cell corpse. (f) ZD region with spermatocysts in advanced state of degeneration occupy the predicted position of L-PrM cysts in this specimen (see Figs. 1 and 2). Cysts are atrophic and have Sertoli cells only with/without TUNEL-positive germ-cell remnants. (g) M-stage cysts (bottom) and round spermatid stage cysts (upper left) are consistently TUNEL-negative. (h) Positive control of M-stage and round spermatid-stage spermatocysts after DNase-I treatment showing that access of the TdT enzyme is not impeded. Scale bars, $25 \mu \mathrm{m}$. 


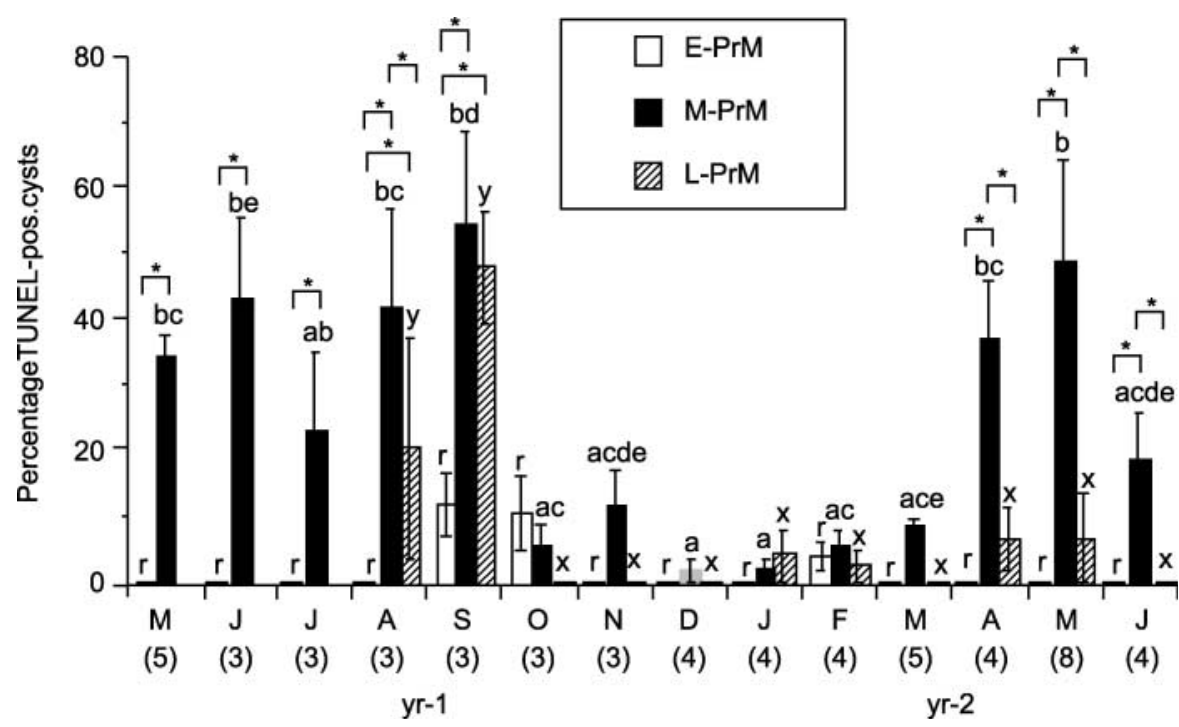

Figure 7 Seasonal and stage-related changes in TUNEL labelling of spermatocysts in S. acanthias. Values represent the mean percentage \pm S.E.M. of TUNEL-positive spermatocysts at E-, M- and L-PrM stages of development. GZ cysts were rarely labelled and not scored. Percentage values were arcsine square-root-transformed and analyzed by two-way ANOVA. Month-by-month differences within each stage $(P<0.001)$, between stages $(P<0.001)$ and their interaction $(P<0.001)$ were significant. The Student-Newman-Keuls multiple-comparison test was used to determine which months differed significantly within a given stage $(P<0.05)(\mathrm{E}-\operatorname{PrM}, \mathrm{r}-\mathrm{s} ; \mathrm{M}-\operatorname{PrM}, \mathrm{a}-\mathrm{e} ; \mathrm{L}-\operatorname{PrM}, \mathrm{x}-\mathrm{y})$. Differences between stages in a given month are indicated with*. Where no bar is shown for a given stage, TUNEL staining was absent. L-PrM cysts were absent from the progression between May and July of year 1 .

transition is due to spermatogonial apoptosis, suggesting that the advance from E-PrM to M-PrM stages is a seasonally regulated control point that determines the cyst numbers of subsequent stages. Thus apoptosis is a major mechanism controlling spermatogenesis, and determines the number of cysts that progress to the final spermatogonial division (L-PrM stage), advance into meiosis and, ultimately, reach the mature spermatid stage.

Within the aborted M-PrM cysts, spermatogonia coalesce to form multinucleate giant cells, a phenomenon probably facilitated by the opening or dissolution of the intercellular bridges between germ cells (Pudney 1995). The multinucleate giant cells are eventually phagocytosed by the Sertoli cells over a period of 10 months after which the ZD cysts are resorbed in the epigonal organ, a lymphomyeloid organ associated with the mature surface of the testis. This protracted nature of apoptosis is rather unusual considering the rapid clearance of apoptotic cells (a few hours at most) in other tissues (Manfredi et al. 2002). Immature spermatogonial cysts rarely undergo total degeneration (see Fig. 2B in Callard et al. 1998), but often contain a scattering of single apoptotic spermatogonia throughout the cyst. The criterion chosen to designate a cyst as TUNEL-positive was actually conservative (a spermatocyst was designated as TUNEL-positive if it contained three or more TUNEL-positive cells, a standard previously applied to rat seminiferous tubules (Lee et al. 1997)), which further validates the data of the temporal nature and strict stage-dependency of apoptosis reported here. These descriptions of germ-cell apoptosis in Squalus, as assessed by the TUNEL assay, have been verified by three other assays, i.e. biochemical analysis of DNA fragmentation (Callard et al. 1995), Acridine Orange vital staining of living testis slices (McClusky et al. 1996) and transmission electron microscopy (L.M. McClusky, unpublished observations). Our findings, however, differ from those reported in the spotted ray, Torpedo marmorata, which show no stage-dependency and cell-type specificity of testicular apoptosis (Prisco et al. 2003). Since a ZD has also been noted in each testicular lobe of the Atlantic stingray, Dasyatis sabina (Maruska et al. 1996), and a ZD and stage-dependent premeiotic apoptosis seen in the little skate, Raja erinacea (L.M. McClusky, unpublished observations), the different mode of testicular apoptosis in Torpedo is difficult to explain other than to suggest the tempering effects of environmental factors peculiar to the Mediterranean sea where this species was studied.

The seasonal appearance of a ZD implicates the brainhypothalamo-pituitary-testicular axis in the control of germ-cell apoptosis specifically at the spermatogoniaspermatocyte transition in the spiny dogfish shark testis in vivo (Simpson \& Wardle 1967), but it is likely that environmental factors are also involved. This conclusion is based on findings in the European spotted dogfish (Scyliorhinus canicula), in which a ZD with a fixed number of cyst layers, more or less in the same position to that occurring seasonally in Squalus, can be induced by hypophysectomy (provided sea-water temperature is near summer-season values), while replacement with shark hypophysial extracts, but not mammalian gonadotrophins, can prevent the appearance of the ZD (Dobson \& Dodd 1977a). Although the identity of the shark gonadotrophin 
is not yet known, these findings are in broad agreement with the demonstrated role of one of the pituitary gonadotrophins $(\mathrm{FSH})$ as an indispensable survival factor for the last spermatogonial cyst stage in another lower vertebrate, the newt (Yazawa et al. 2002). These data in lower vertebrates, together with data in rodents which demonstrate the acute dependency of differentiating spermatogonia and preleptotene spermatocytes on FSH for their survival (Boitani et al. 1995, Meachem et al. 1999, Allan et al. 2004), probably suggest an evolutionarily conserved feature of gonadotrophin action on differentiating spermatogonia. Since the population of differentiating spermatogonia in rodents is also subject to strict density-dependent regulation via apoptosis (De Rooij 2001), it might be that the latter is phylogenetically a relatively late-derived feature in the regulation of spermatogonial cell kinetics.

In all vertebrates, the spatiotemporal synchronization of steroidogenic and spermatogenic developments ensures timeous and optimal production of spermatozoa. Results presented here show that the resumption of the developmental progression of mature spermatogonial cysts in the fall coincides in time and space with a corresponding increase in the number of mature spermatid cysts, findings which are also noted in other elasmobranchs (Garnier et al. 1999, Tricas et al. 2000). These findings in Squalus, to some extent, complement those of previous in vitro experiments on isolated spermatocysts. For example, when a mixed population of PrM cysts, isolated from Squalus that lack mature spermatid cysts and have a natural ZD at the spermatogonia-spermatocyte transition, are placed in basal medium, these cysts gradually, spontaneously and stage-dependently (large PrM cysts $\gg$ small PrM cysts) enter apoptosis in vitro (Callard et al. 1995, McClusky et al. 1996), results which are consistent with the absence of survival factors. However, addition of a gonadotrophin-mimicking agent (3-isobutyl-1-methylxanthine (IBMX), $1 \mathrm{mM}$ ), which is known to raise testosterone and oestradiol secretion in such PrM cysts to some extent (Cuevas \& Callard 1992a), causes a significant decrease in both DNA synthesis and DNA fragmentation in PrM cysts (Callard et al. 1995). Similarly, added oestradiol and androgens significantly reduce the percentage of apoptotic cysts with no effect on $\left[{ }^{3} \mathrm{H}\right]$ thymidine incorporation in spermatogonial cysts in vitro (Betka \& Callard 1998; L.M. McClusky, unpublished observations). By extension and given that (1) mature spermatid cysts, which are absent in April-May, are major sites for the synthesis of androgen-binding protein and for the secretion of testosterone and its precursors (Simpson \& Wardle 1967, Mak \& Callard 1989, Sourdaine et al. 1990, Cuevas \& Callard 1992a), (2) classical nuclear oestrogen and androgen receptors are concentrated in the PrM region of the shark testis (Callard et al. 1985, Cuevas \& Callard 1992b), (3) the vascular pathway in Squalus is countercurrent to the spermatogenic progression, i.e. PoM cysts to GZ cysts (Cuevas et al. 1992) and (4) hypophysectomy of male dogfish (Scyliorhinus) leads only to a small decrease in circulating androgen (Dobson \& Dodd 1977a), overall reconciliation of all these observations in dogfish sharks suggests that the developmental advance of mature spermatogonial cysts in sharks is dependent not only on de novo testosterone and/or oestrogen synthesis in PrM cysts, but also on those synthesized in mature-spermatid cyst stages, when they are present in the spermatogenic progression. These conclusions are consistent with the coincident increased M-PrM-cyst apoptosis in April-May and a concurrent deficiency of mature spermatids in the spermatogenic progression.

Other novel observations in the immature PrM region were the apparent coordination of spermatogonial and Sertoli-cell proliferative activities, Sertoli-cell dominance of cyst-proliferative activities during the year, except for a brief period in December and during the spring-summer months, and the relative resistance of immature cysts to seasonal apoptosis during the first nine divisions. The steady increase in cyst diameter during the spermatogonial stages is solely due to the proliferation of spermatogonia and Sertoli cells, at least for the first nine divisions. Careful analysis of DNA synthesis data in organ-culture experiments of immature rat testes similarly reveal an inverse relationship between germ-cell and Sertoli-cell proliferation, such that germ-cell DNA synthesis is low when Sertoli-cell DNA synthesis is elevated and vice versa (Schlatt et al. 1999). Furthermore, FSH regulates both Sertoli-cell and differentiating spermatogonial DNA synthesis (Boitani et al. 1995, Schlatt et al. 1999). By extension then, one explanation could be that seasonal alternating patterns in PCNA immunoreactivity in Sertoli and germ cells in sharks reflect variations in gonadotrophin secretion and/or changes in cell-type-specific responses to gonadotrophin secretion in these immature cysts. In this regard, it is worth noting that both mRNA and protein PCNA expression are known to be under direct gonadotrophin (FSH) control in another gonadal cell system, rat granulosa cells (the female equivalent of Sertoli cells; El-Hefnawy \& Zeleznik 2001), and Sertoli-cell proliferation in foetal and neonatal rodent testis is FSH-stimulated (Sharpe et al. 2003, Allan et al. 2004). Nevertheless, the data presented here show that although Sertoli-cell proliferation dominates immature spermatogonial cyst cell kinetics for most of the year, the decreases in Sertoli-cell PCNA immunoreactivity correspond temporally exactly with the time of M-PrM-cyst abortions culminating in ZD formation, suggesting that April-May is the beginning of a 4-month period of gonadotrophin deficit, as was also suggested by Simpson \& Wardle (1967). Secondly, the developmental progression of immature shark spermatogonia (GZ and E-PrM cysts) is most likely directly gonadotrophin-independent (Dobson \& Dodd 1977b) and/or may be Sertoli cell-mediated, e.g. via seasonally regulated diffusable factors (Loir 1994) and contact-dependent mechanisms (Mather et al. 1990, Zhou et al. 1993, Loir 1999). Indeed, unidentified growth-stimulatory and -inhibitory bioactivities present in spent media of cultured 
Squalus Sertoli cells regulate spermatogonial DNA synthesis in vitro, depending on the time of year (DuBois \& Callard 1993). With regards to this last point, it should be noted that when a mixed population of PrM cysts, isolated from Squalus caught in late April (these animals have no ZD yet), are placed in culture in basal medium, none of these cysts enter apoptosis spontaneously, and are completely unresponsive to gonadotrophin-mimicking agents, steroids or growth factors (L.M. McClusky, unpublished observations), despite the fact that Sertoli cells in immature spermatogonial cysts are proliferatively active (this study). These observations, together with data of the observed complete lack of PCNA immunoreactivity in immature spermatogonia in winter, are further evidence that immature spermatogonia are in a state of developmental arrest during winter, an effect that is probably Sertoli-cellmediated.

An interesting observation was the pronounced gonocytogenesis in the germinal ridge coincident with the M-PrM-cyst abortions culminating in ZD formation in April/May-September, and vice versa in winter. These germinal stem cells are not found in a continuous line along the length of the germinal ridge, but are spatially spread out in clusters that expand and are PCNA-immunoreactive in spring-summer. Clusters of undifferentiated spermatogonia are similarly found all along the length of the rodent seminiferous tubule (De Rooij \& Janssen 1987), their appearance thought to be related to a Sertoli-cellmediated regulatory feedback mechanism that controls the ratio between self-renewal and differentiation of spermatogonial stem cells (De Rooij 2001, Tadokoro et al. 2002). Whatever the triggers of season-dependent increased gonocytogenesis in the shark testis, these findings suggest the presence of a seasonal homeostatic feedback mechanism that senses apoptotic deletion of differentiated spermatogonial clones and, in response, stimulates spermatogenic stem-cell proliferation. This might, to some extent, also explain the observed relatively constant numbers of GZ and E-PrM cysts in the progression throughout the year.

An unexpected finding was the strong PCNA immunoreactivity of the large spherical Sertoli-cell nuclei in evacuated cysts. In many nonmammalian vertebrates, Sertoli cells of evacuated lobules and cysts are known to hypertrophy, become densely lipoidal and even modify their glycoprotein content, presumably for as-yet-unknown functions post-spermiation (Lofts 1968, Kinnberg et al. 2000, Saez et al. 2001). These observations in the spiny dogfish may be interpreted similarly, but to our knowledge this is the first report of Sertoli-cell proliferation post-spermiation, a finding that needs further investigation.

Notwithstanding the difficulties associated with seasonal studies in elasmobranchs, the spatial and temporal aspects of spermatogenesis in these ancient vertebrates render these organisms as alternative models for the stepwise analysis of spermatogenic processes. Since sea temperature is clearly implicated in the waxing and waning of testicular activities of other elasmobranchs (Garnier et al. 1999, Tricas et al. 2000), further studies are required to establish whether environmental cues also have a role in cell-proliferative and cell-death activities during spermatogenesis in the spiny dogfish shark.

\section{Acknowledgements}

This research was carried out in part at the Mount Desert Island Biological Laboratory, Salisbury Cove, ME, USA and Boston University, and supported in part by a fellowship from the National Research Foundation of South Africa. The assistance of Andy Sexton (Marine Biological Laboratory, Woods Hole, MA, USA), Janet Fields and Vic Nordahl (National Marine Fisheries Service, Woods Hole, MA, USA), Jim Francesconi (North Carolina Division of Marine Fisheries, Morehead City, NC, USA) and Arnold Howe (Massachusetts Division of Marine Fisheries, Cape Cod Bay, MA, USA) in the collection of shark specimens is greatly appreciated. A special word of thanks is extended to Dr Gloria Callard (Boston University) for helpful discussions, and to Dr Jeffrey Pudney (Brigham and Women's Hospital and Harvard Medical School) for critically reading the manuscript.

\section{References}

Allan CM, Garcia A, Spaliviero J, Zhang F-P, Jimenez M Huhtaniemi I \& Handelsman DJ 2004 Complete Sertoli cell proliferation induced by follicle-stimulating hormone ( $\mathrm{FSH})$ independently of luteinizing hormone activity: Evidence from genetic models of isolated FSH action. Endocrinology 145 1587-1593.

Betka M \& Callard GV 1998 Negative feedback control of the spermatogenic progression by testicular oestrogen synthesis: insights from the shark testis. Acta Pathologica, Microbiologica et Immunologica Scandinavica 106 252-258.

Boitani C, Politi MG \& Menna T 1993 Spermatogonial cell proliferation in organ culture of immature rat testis. Biology of Reproduction $48761-767$.

Boitani C, Stefanini M, Fragale A \& Morena AR 1995 Activin stimulates Sertoli cell proliferation in a defined period of rat testis development. Endocrinology 136 5438-5444.

Callard GV, Pudney JA, Mak P \& Canick J 1985 Stage-dependent changes in steroidogenic enzymes and estrogen receptors during spermatogenesis in the testis of the dogfish Squalus acanthias. Endocrinology 117 1328-1335.

Callard GV, Jorgensen JC \& Redding JM 1995 Biochemical analysis of programmed cell death during premeiotic stages of spermatogenesis in vivo and in vitro. Developmental Genetics 16 140-147.

Callard GV, McClusky LM \& Betka M 1998 Apoptosis as a normal mechanism of growth control and target of toxicant actions during spermatogenesis. In New Developments in Marine Biotechnology, pp 125-128. Eds Y le Gal \& HO Halvorson. New York: Plenum Press.

Cuevas ME \& Callard GV 1992a In vitro secretion by staged spermatocysts (Sertoli/germ cell units) of dogfish (Squalus acanthias) testis. General and Comparative Endocrinology 88 151-165.

Cuevas ME \& Callard GV 1992b Androgen and progesterone receptors in shark (Squalus) testis: characteristics and stage-related distribution. Endocrinology 130 2173-2182.

Cuevas ME, Miller W \& Callard GV 1992 Sulfoconjugation of steroids and the vascular pathway of communication in dogfish testis. Journal of Experimental Zoology 264 119-129.

De Rooij DG 2001 Proliferation and differentiation of spermatogonial stem cells. Reproduction 121 347-354.

De Rooij DG \& Janssen JM 1987 Regulation of the density of spermatogonia in the seminiferous epithelium of the chinese hamster: 
I. Undifferentiating spermatogonia. Anatomical Record 217 $124-130$.

De Rooij DG \& Van Dissel-Emiliani FMF 1997 Regulation of proliferation and differentiation of stem cells in the male germ line. In Stem Cells, pp 283-313. Ed. CS Potten. London: Academic Press.

Dobson S \& Dodd JM 1977a Endocrine control of the testis in the dogfish Scyliorhinus canicula L. I. Effects of partial hypophysectomy on gravimetric, hormonal and biochemical aspects of testicular function. General and Comparative Endocrinology 32 41-52.

Dobson S \& Dodd JM 1977b Endocrine control of the testis in the dogfish Scyliorhinus canicula L. II. Histological and ultrastructural changes in the testis after partial hypophysectomy (ventral lobectomy). General and Comparative Endocrinology 32 53-71.

DuBois W \& Callard GV 1993 Culture of intact Sertoli/germ cell units and isolated Sertoli cells from Squalus testis II. Stimulatory effects of insulin and IGF-I on DNA synthesis in premeiotic stages. Journal of Experimental Zoology $267233-244$.

El-Hefnawy T \& Zeleznik AJ 2001 Synergism between FSH and activin in the regulation of proliferating cell nuclear antigen (PCNA) and cyclin D2 expression in rat granulosa cells. Endocrinology 142 $4357-4362$.

Garnier DH, Sourdaine P \& Jégou B 1999 Seasonal variations in sex steroids and male sexual characteristics in Scyliorhinus canicula. General and Comparative Endocrinology 116 281-290.

Gavrieli Y, Sherman Y \& Ben-Sasson SA 1992 Identification of programmed cell death in situ via specific labelling of nuclear DNA fragmentation. Journal of Cell Biology 119 493-501.

Hall PA \& Woods AL 1990 Immunohistochemical markers of cellular proliferation: achievements, problems and prospects. Cell and Tissue Kinetics 23 505-522.

Holstein A-F 1969 Zur frage der lokalen steuerung der spermatogenese beim dornhai (Squalus acanthias L.). Zeitschrift für Zellforschung 93 265-281.

Jones BC \& Geen GH 1977 Reproduction and embryonic development of spiny dogfish (Squalus acanthias) in the Strait of Georgia, British Columbia. Journal of the Fisheries Research Board of Canada 34 1286-1292.

Kinnberg K, Korsgaard B, Bjerregaard P \& Jespersen A 2000 Effects of nonylphenol and $17 \beta$-estradiol on vitellogenin synthesis and testis morphology in male platyfish Xiphophorus maculates. Journal of Experimental Biology 203 171-181.

Lee J, Richburg JH, Younkin SC \& Boekelheide K 1997 The Fas system is a key regulator of germ cell apoptosis in the testis. Endocrinology 138 2081-2088.

Lofts B 1968 Patterns of testicular activity. In Perspectives in Endocrinology. Hormones in the Lives of Lower Vertebrates, pp 239-304. Eds EJW Barrington \& CB Jorgenson. New York: Academic Press.

Loir M 1994 In vitro approach to the control of spermatogonia proliferation in the trout. Molecular and Cellular Endocrinology 102 $141-150$

Loir M 1999 Spermatogonia of rainbow trout: II. In vitro study of the influence of pituitary hormones, growth factors and steroids on mitotic activity. Molecular Reproduction and Development $\mathbf{5 3}$ 434-442.

Mak P \& Callard GV 1989 A novel steroid binding protein in the testis of the dogfish Squalus acanthias. General and Comparative Endocrinology 68 104-112.

Manfredi AA, lannacone M, D'Auria F \& Rovere-Querini P 2002 The disposal of dying cells in living tissues. Apoptosis 7 153-161.

Maruska KP, Cowie EG \& Tricas TC 1996 Periodic gonadal activity and protracted mating in elasmobranch fishes. Journal of Experimental Zoology 276 219-232.

Mather JP, Attie KM, Woodruff TK, Rice GC \& Phillips DM 1990 Activin stimulates spermatogonial proliferation in germ-Sertoli cell cocultures from immature rat testis. Endocrinology 127 $3206-3214$.
McClusky LM, Betka M, Miller D \& Callard GV 1996 Analysis of the apoptotic form of programmed cell death (PCD) during spermatogenesis in spiny dogfish (Squalus acanthias). Bulletin of the Mount Desert Island Biological Laboratory 35 96-97.

Meachem SJ, McLachlan RI, Stanton PG, Robertson DM \& Wreford NG 1999 FSH immunoneutralization acutely impairs spermatogonial development in normal adult rats. Journal of Andrology 20 $756-762$.

Ortego LS, Hawkins WE, Walker WW, Kroll RM \& Benson WH 1994 Detection of proliferating cell nuclear antigen in tissues of three small fish species. Biotechnic and Histochemistry 69 317-323.

Piferrer FC \& Callard GV 1995 Inhibition of deoxyribonucleic acid synthesis during premeiotic stages of spermatogenesis by a factor from testis-associated lymphomyeloid tissue in the dogfish shark (Squalus acanthias). Biology of Reproduction 53 390-398.

Prisco M, Liguoro A, Comitato R, Cardon A, D'Onghia B, Ricchiari L \& Angelini F 2003 Apoptosis during spermatogenesis in the spotted ray Torpedo marmorata. Molecular Reproduction and Development 64 341-348.

Pudney J 1995 Spermatogenesis in nonmammalian vertebrates. Microscopy Research and Technique 32 459-497.

Pudney J \& Callard GV 1984 Identification of Leydig-like cells in the interstitium of the shark testis (Squalus acanthias). Anatomical Record 209 311-330.

Saez FJ, Mardid JF, Alonso E \& Hernandez F 2001 Glycan composition of follicle (Sertoli) cells of the amphibian Pleurodeles waltl. A lectin histochemical study. Journal of Anatomy 198 673-681.

Schlatt S, Zhengwei Y, Meehan T, De Kretser DM \& Loveland KL 1999 Application of morphometric techniques to postnatal rat testes in organ culture: insights into testis growth. Cell and Tissue Research 298 335-343.

Sharpe RM, McKinnell C, Kivlin C \& Fisher JS 2003 Proliferation and functional maturation of Sertoli cells, and their relevance to disorders of testis function in adulthood. Reproduction 125 769-784.

Simpson TH \& Wardle CS 1967 A seasonal cycle in the testis of the spurdog, Squalus acanthias, and the sites of $3 \beta$-hydroxysteroid dehydrogenase activity. Journal of the Marine Biological Association of the United Kingdom 47 699-708.

Sourdaine P, Garnier DH \& Jégou B 1990 The adult dogfish (Scyliorhinus canicula L.) testis: a model to study stage-dependent changes in steroid levels during spermatogenesis. Journal of Endocrinology 127 451-460.

Stanley HP 1966 The structure and development of the seminiferous follicle in Scyliorhinus canicula and Torpedo marmorata (Elasmobranchii). Zeitschrift für Zellforschung 75 453-468.

Tadokoro Y, Yomogida K, Ohta H, Tohda A \& Nishimune Y 2002 Homeostatic regulation of germinal stem cell proliferation by the GDNF/FSH pathway. Mechanisms of Development 113 29-39.

Tricas TC, Maruska KP \& Rasmussen LEL 2000 Annual cycles of steroid hormone production, gonad development, and reproductive behavior in the Atlantic stingray. General and Comparative Endocrinology 118 209-225.

Yazawa T, Yamamoto T, Jin Y \& Abé S-I 2002 Follicle-stimulating hormone is indispensable for the last spermatogonial mitosis preceding meiosis initiation in newts (Cynops pyrrhogaster). Biology of Reproduction 66 14-20.

Zhou B, Watts LM \& Huston JM 1993 Germ cell development in neonatal mouse testis in vitro requires müllerian inhibiting substance. Journal of Urology $150613-616$.

Received 19 January 2004

First decision 27 April 2004

Revised manuscript received 27 September 2004

Accepted 7 October 2004 